\title{
PENINGKATAN USAHA TELUR ASIN ASAP
}

\author{
Wara Pratitis Sabar' dan Nur Her Riyadi Parnanto \\ I Prodi Peternakan Fakultas Pertanian UNS \\ ${ }_{2}$ Prodi Ilmu Teknologi Hasil Fakultas Pertanian UNS \\ Email: suprayogiwara@yahoo.co.id
}

\begin{abstract}
Smoke salted egg production business now stands at Karanganyar where production capacity is still low. The problem faced are the continuity of supply of duck eggs, the smoker tools that low capacity and no have of P-IRT permits. Increased smoke salted eggs can be carried out by I) interlacement partnerships with suppliers duck eggs, 2) facilitating the permitting P-IRT, 3) introduction of appropriate technology smoker salted eggs and 4) mentoring. The activities that have been carried out to increase the impact of smoke where the salted egg business continuity and increased production capacity, expansion of marketing and revenue enhancement partner SMEs.
\end{abstract}

Keywords: salted smoked, fumigation technology, production

\section{PENDAHULUAN}

Umumnya usaha peternakan itik ditujukan untuk bebek petelur. Sebelum seorang peternak memulai usaha peternakan bebek, harus menyiapkan diri dengan pemahaman tentang perkandangan, bibit unggul, pakan ternak, pengelolaan dan pemasaran hasil. Misalnya bagaimana pemeliharaan anak bebek (5-8 minggu), pemeliharaan bebek dara (umur 8-20 minggu ke atas) dan pemeliharaan bebek petelur (umur 20 minggu ke atas) (Fajararizz, 2010). Masa produksi telur yang ideal adalah selama 1 tahun. Produksi telur rata-rata bebek lokal berkisar antara 200-300 butir per tahun dengan berat rata-rata 70 gram (Anonim, 2010).

Hasil budidaya ternak bebek petelur terdiri atas hasil utama, sampingan dan limbah. Hasil utama berupa telur, hasil sampingan berupa bebek afkir dan bulu dan limbah berupa feses. Telur bebek selain dapat dimanfaatkan dalam bentuk segar, juga dapat diolah menjadi martabak, telur gembung, kerupuk dan telur asin (yang paling popular). Bebek afkir dapat diolah menjadi gulai bebek cabai hijau, bebek goreng, abon, baso, nugget atau olahan lainnya, sedangkan bulu dapat dijadikan bahan pengisi kasur, bantalan kursi, jaket, hiasan dinding, penjepit rambut atau kerajinan tangan lainnya. Feses dapat dimanfaatkan sebagai pupuk kandang atau pakan ikan lele/belut.

Penggunaan telur bebek sebagai bahan baku telur asin tidak dapat digantikan oleh telur unggas lain. Telur asin yang berkualitas baik adalah yang kuning telurnya masir (berminyak), tetapi putih telurnya tidak terlalu asin. Prospek dan peluang pasarnya masih terbuka luas, karena telur asin dapat disimpan dalam jangka waktu yang lebih lama daripada telur segar. Telur asin sebenarnya dapat menjadi komoditi ekspor jika telur tersebut bebas Salmonella, proses pembuatannya higienis dan hasilnya berkualitas baik (kuning telur masir tetapi putih telur tidak terlalu asin) (Anonim, 2011).

Pengolahan telur bebek menjadi telur asin menyebabkan masa simpan menjadi lebih panjang, dapat menambah citarasa, sekaligus mengurangi bau amisnya. Perkembangan pemasaran telur asin terutama di kota besar/ kota pariwisata sangat menjanjikan. Telur asin 
juga sudah lazim dijadikan buah tangan yang istemewa. Telur asin bebek sudah menjadi trademark tersendiri (Dwi Margi S, 2013). Salah satu UKM yang mengolah telur bebek menjadi telur asin adalah UKM Hartini yang berada di wilayah Jaten Kabupaten Karanganyar. UKM ini baru sekitar kurang lebih 1,5 tahun menggeluti usaha pembuatan telur asin yang diasap.

UKM Hartini mengolah telur asin yang diasap dimana produksi telur asin asap sebanyak 240 butir per 2 hari sekali tergantung ketersediaan telur bebek. Telur bebek dibeli dari para peternak bebek yang berada di Kabupaten Karanganyar maupun dari Kabupaten Sukoharjo dengan harga per butirnya sebesar Rp 1.500 - Rp 1.800/ butir. Telur bebek yang diasinkan ini merupakan telur-telur segar yang baru ditelurkan dari indukan. Jika telur yang digunakan merupakan telur bebek lama maka hasil telur asinnya mempunyai kualitas yang tidak bagus. Kontinuitas ketersediaan telur bebek untuk diolah menjadi telur asin menjadi salah satu kendala yang dihadapi oleh UKM ini. Berikut ini gambar mengenai proses produksi telur asin asap :
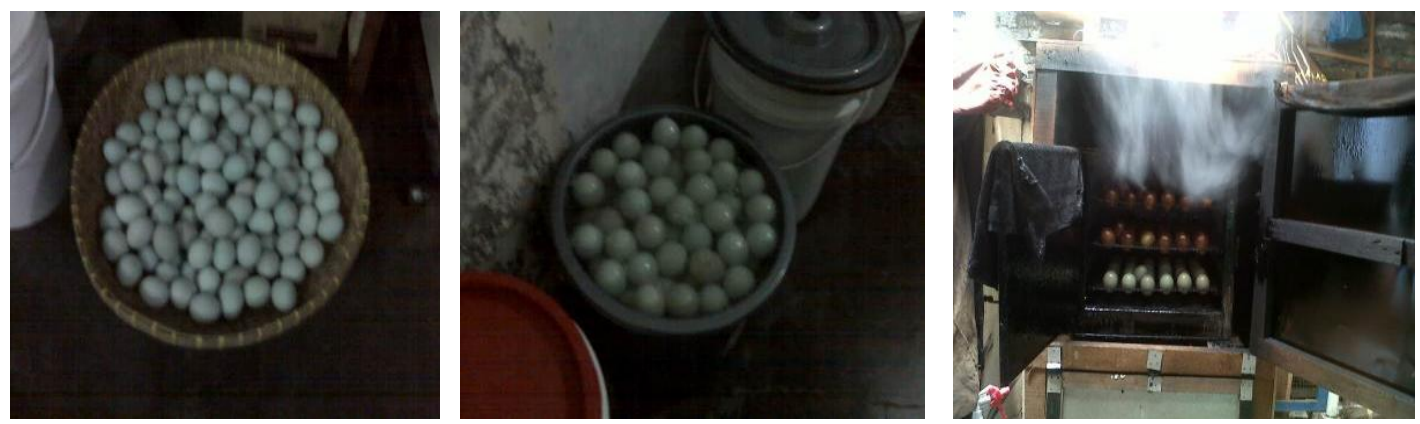

Gambar 1. Proses Produksi Telur Asin Asap

Ide membuat telur asin asap ini terinspirasi dari telur asin asap dari Brebes. Telur asin bebek yang dipasarkan di Kota Solo dan sekitarnya belum banyak yang merupakan telur asin asap sehingga hal ini lah yang membuka peluang usaha bagi UKM Hartini untuk berusaha di bidang ini. Proses produksi telur asin asap sama seperti membuat telur asin bebek, hanya bedanya setelah menjadi telur asin kemudian dilakukan pengasapan dengan menggunakan oven roti selama $5-6$ jam. Kapasitas pengasapan kurang lebih 120 butir per sekali proses. Kenyataan yang terjadi sering telur asin tersebut tidak sama tingkat kematangannya dan gosong. Akibatnya telur asin asap tersebut tidak dapat dijual dan mengalami kerugian. Daya tahan telur asin asap ini sampai kurang lebih 1 bulan untuk dapat dikonsumsi.

Walaupun sudah memiliki kemasan yang relative marketable, namun usaha telur asin asap tersebut belum memiliki sertifikat/ perijinan PI-RT (Pangan Industri Rumah
Tangga) dan SP (Sertifikat Penyuluhan) dari Dinas Kesehatan setempat. Belum dimilikinya sertifikat perijinan tersebut karena keterbatasan pengetahuan dan adanya informasi yang keliru bahwa pengurusan perijinan tersebut berbelit-belit dan membutuhkan dana yang lumayan besar. Belum dimilikinya PI-RT dapat menjadi kendala dalam pemasaran karena sekarang ini konsumen semakin kritis terhadap syarat keamanan suatu produk pangan.

Pemasaran telur asap dipasarkan di Kota Solo terutama di toko oleh-oleh dan pesanan rutin yang datang dari daerah Kalimantan Selatan. Sistem pembayaran ada yang dengan cara dibayar tunai maupun konsinyasi. Pemasaran telur asap sampai sejauh ini belum menjadi kendala meskipun belum memiliki sertifikat PI-RT karena pesaing telur asin asap di Kota Solo masih sangat jarang.

Tujuan dari penulisan artikel ini adalah: 
1. Penjalinan kemitraan dengan suplier telur bebek dalam rangka kontinuitas supply telur bebek di tingkat ukm mitra

2. Fasilitasi perijinan P-IRT

3. Introduksi tehnologi tepat guna pengasapan.

\section{METODE}

Metode pelaksanaan dalam kegiatan ini meliputi survey untuk penjalinan kemitraan, fasilitasi perijinan, introduksi tehnologi tepat guna dan pendampingan (sabar, dan Parnanto, 2014).

1. Penjalinan kerjasama pengadaan bahan baku

a. Caranya tim pelaksana berdiskusi dengan pemilik UKM Hartini "Ndog Ireng" mengenai kerjasama yang sudah dilakukan dan belum dilakukan dengan para peternak

b. Tim bersama dengan ukm mitra melakukan survey ke peternak bebek yang cara pemeliharaannya di"angon" di sawah

c. Tim melakukan pendampingan kerjasama tersebut

2. Fasilitasi Pengurusan PI-RT dan SP di Dinas Kesehatan

a. Caranya tim pengabdian berdiskusi dengan pemilik "Ndog Ireng" mengenai persyaratan-persyaratan yang harus dipenuhi dalam rangka pengajuan sertifikat PI-RT dan SP ke Dinas Kesehatan

b. Tim pengabdian memfasilitasi dan mendampingi hal-hal yang diperlukan dalam rangka pengajuan $\mathrm{PI}-\mathrm{RT}$ dan SP seperti kebersihan tempat produksi, sanitasi, kebersihan peralatan produksi supaya lolos pada waktu visitasi yang dilakukan oleh Dinas Kesehatan

c. Tim pengabdian mendampingi dalam pengisian formulir pengajuan PI-RT dan melakukan pemantauan sampai sejauh mana formulir tersebut telah diproses oleh Dinas Kesehatan

3. Introduksi tehnologi tepat guna pengasapan telur asin
Tehnologi tepat guna ini memiliki kapasitas pengasapan 300 butir telur bebek untuk sekali pengasapan dan waktu yang dibutuhkan kurang lebih 3 jam. Terbuat dari bahan steinless steel, besi siku dilengkapi dengan motor pengisap asap. Tim melakukan pendampingan setelah alat tersebut diintroduksikan.

\section{HASIL DAN PEMBAHASAN}

Tim Pengabdian melakukan koordinasi dengan ukm mitra dan mendiskusikan kegiatan-kegiatan yang akan dilaksanakan bersama dalam mengembangkan usaha telur asin asap. Usaha yang telah dilaksanakan untuk itu adalah:

\section{A. Pengurusan ijin P-IRT untuk UKM Hartini}

Tim Pengabdian melakukan pendampingan dalam pengurusan ijin P-IRT (Pangan Industri Rumah Tangga). Sebelum melakukan proses pengajuan perijinan, Tim Pengabdian bersama dengan ukm mitra melakukan pembenahan tempat produksi agar terjaga standart kebersihan dan sanitasinya. Diharapkan dari pembenahan ini akan dapat meminimalisasi kandungan bakteri/ mikrobia dalam telur asin.

Tim Pengabdian memonitor perkembangan pengajuannya ke Dinas Kesehatan karena proses perijinannya membutuhkan tahapan dan waktu yang relatif lama. Pengurusan perijinan dimulai dari pengisian formulir yang dilengkapi dengan denah lokasi usaha, fotokopi ktp, pas photo, dan surat keterangan dari pemerintah desa tentang kebenaran usaha ndok ireng berada pada wilayah desa tersebut. Setelah formulir diserahkan kepada Dinas Kesehatan, pemohon dipanggil untuk mengikuti penyuluhan keamanan pangan berbarengan dengan para pemohon lainnya yang mengajukan perijinan. UKM Hartini memperoleh sertifikat Penyuluhan Keamanan Pangan dengan Nomor : 075/3313/ 14 pada tanggal 4 September 2014. Petugas meminta sampel produk yang akan dilakukan uji laboratorium terhadap kandungan mikrobia 
apakah masih dalam batas wajar atau tidak layak konsumsi karena membahayakan bagi kesehatan.

Hasil uji laboratorium menyatakan bahwa kandungan mikrobia dalam ndog ireng dalam batas yang wajar sehingga aman dan layak untuk dikonsumsi. Sertifikat perijinan akhirnya dapat diperoleh dengan P-IRT No : 2033313750162-18 pada tanggal 9 September 2014. Dengan diperolehnya perijinan ini, kemasan produk mengalami perbaikan dimana akan dicantumkannya $\mathrm{P}$ IRT dalam kemasan. Konsekuensi dari diperolehnya perijinan ini adalah jaminan pada higyenitas proses produksi, sanitasi yang baik dan keamanan pangan pada produk yang dihasilkan.

Dengan diperolehnya perijinan P-IRT oleh mitra maka mitra dapat memperluas pasar baik daerah pemasaran maupun pasar sasarannya ke swalayan, supermarket, toko oleh-oleh yang ketat seleksinya mengenai perijinan keamanan pangan. Sampai saat ini, mitra masih melakukan negosiasi dengan supermarket dalam penjajakan kerjasama pemasaran.

\section{B. Introduksi alat pengasap telur asin}

Hasil sosialisasi disepakati bahwa alat pengasap telur asin mempunyai kapasitas produksi sebesar 300 butir telur untuk sekali pengasapan. Hal ini disesuaikan dengan kapasitas pembuatan telur asin untuk sekali produksi. Alat terbuat dari bahan steinless steel yang tidak mudah berkarat. Setelah alat pengasap telur asin ini selesai dikerjakan, kemudian diintroduksikan ke UKM Hartini. Alat pengasap dilengkapi dengan temperatur suhu dan cerobong pembuangan asap yang dilengkapi dengan mesin pengisap asap. Tim menerangkan cara kerja alat tersebut, dimana alat terbagi menjadi dua bagian yaitu bagian dalam yang terbuat dari steinless stell untuk mengasap telur asin dan bagian luar yang terbuat dari besi baja yang digunakan untuk mengurung/ mengumpulkan asap dari pembakaran batok kelapa. Alat ini dilengkapi dengan blower untuk membuang kelebihan asap ke udara bebas dengan menyalurkannya lewat pipa pembuangan. Introduksi alat pengasap dapat dilihat pada gambar berikut:

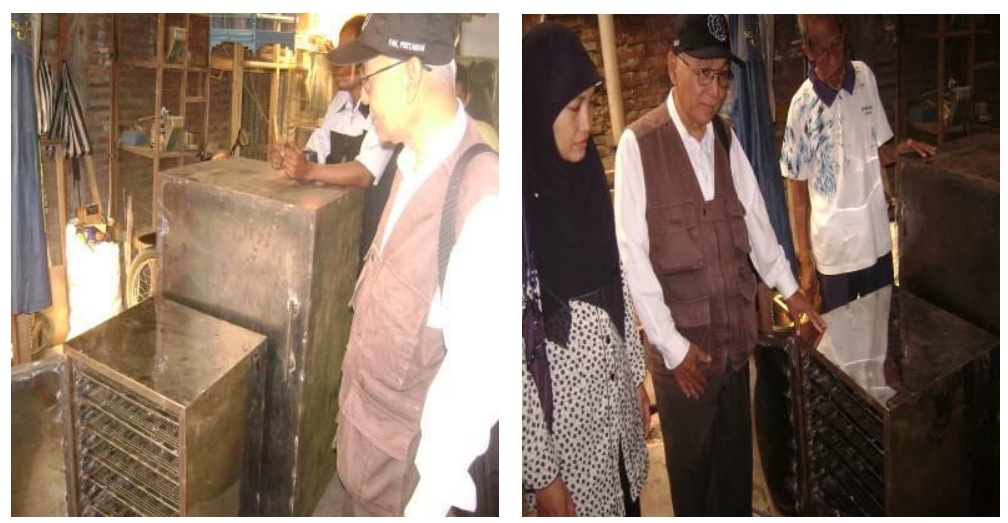

Gambar 2. Introduksi Alat Pengasap di UKM Hartini

Pertama kali alat ini digunakan untuk mengasap 300 butir telur membutuhkan waktu kurang lebih 4 jam dan hasilnya belum seluruh telur berwarna coklat tua namun masih ada yang coklat muda. Hal ini disebabkan karena alat ini masih baru sehingga membutuhkan penyesuaianpenyesuaian dalam penggunaannya dimana sisa-sisa asap belum menempel pada alat yang menyebabkan warna coklat tua pada telur asin. Setelah digunakan beberapa kali, akhirnya telur asap yang dihasilkan sudah sesuai dengan keinginan mitra dimana pada alat pengasap sudah nampak sisa-sisa asap pada dindingnya dimana hal ini mempercepat proses pengasapan. Waktu yang dibutuhkan untuk sekali pengasapan sekarang ini kurang lebih 3 jam dimana waktu ini lebih cepat dari 
alat yang digunakan sebelumnya selama 4 jam. Seluruh telur asin yang diasap dihasilkan warna yang sama dimana pada penggunaan alat terdahulu, tidak seluruh telur asin mempunyai keseragaman warna coklat tua sehingga masih perlu waktu lagi untuk mengasapnya.

\section{Penjalinan Kemitraan Dengan Peternak Bebek}

Telur bebek yang digunakan dalam produksi telur asin di ukm mitra merupakan telur bebek yang budidaya bebeknya "diangon" di sawah. Jika menggunakan telur bebek yang dihasilkan dari budidaya bebek darat dengan cara dikandangkan yang diberi pakan konsentrat, maka kuning telurnya tidak sebesar dan seenak telur bebek yang budidayanya "diangon". Pada saat sekarang ini, relatif sulit mencari telur bebek yang seperti itu. Namun, tidak menutup kemungkinan akan terjalin kemitraan dengan suplier telur bebek. Setelah melalui survei lokasi di daerah Mojolaban bagian barat, Solobaru, Gawok sampai Delanggu akhirnya dapat diidentifikasi sekitar 20 peternak bebek yang dipelihara di lahan persawahan. Ratarata produksi para peternak tersebut sudah ada penadahnya, namun tidak menutup kemungkinan UKM Hartini untuk disupply dari para peternak ini dengan menitipkan uang terlebih dahulu. Akhirnya, ada beberapa peternak yang mau menjdi supplier telur bebek dengan harga $\mathrm{Rp}$ 1.600-Rp 1.700/ butir dengan menyetorkan per minggu sebesar 300 - 600 butir telur bebek. Oleh karena sudah ada pensuplai tetap maka usaha pengasinan telur asin dan pengasapan tidak menemui kendala lagi. Berikut saat survei penjalinan kemitraan dengan peternak bebek dan kontinuitas produksi pengasinan telur.
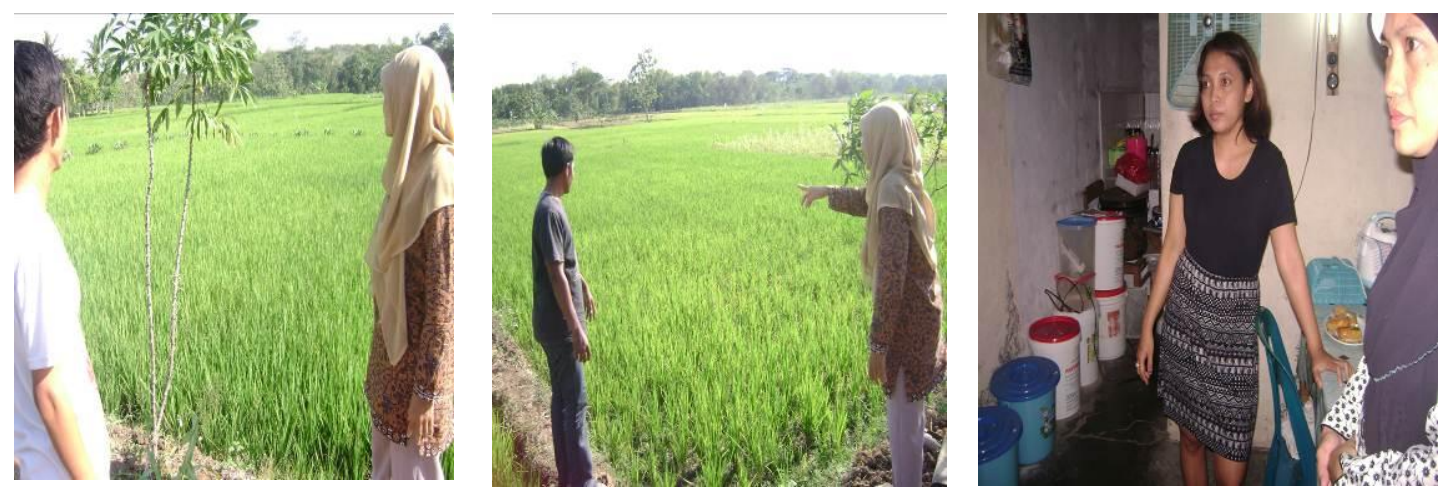

Gambar 3. Penjalinan Kemitraan dengan Para Peternak Bebek

\section{Pendampingan dan monitoring kegiatan}

Tim Pengabdian melakukan pendampingan dan monitoring yang berkesinambungan dengan ukm mitra. Monitoring kegiatan dilakukan minimal 2 minggu sekali. UKM Hartini melakukan pengasinan telur asin relatif mudah dan sederhana hanya dengan menggunakan garam grosok yang dilarutkan dalam air. Telur bebek dibersihkan terlebih dahulu dari kotoran yang menempel dengan cara dicuci bersih dengan air. Kemudian, telur bebek yang telah bersih dimasukkan kedalam ember dimana setiap ember diisi sebanyak 150 butir telur bebek dengan garam sebanyak $1,5 \mathrm{~kg}$ dalam $10 \mathrm{~L}$ air. Konsentrasi larutan garam tersebut sebesar 15\% direndam selama 17 hari. Setelah direndam kemudian direbus selama 2 jam kemudian diasap. Telur bebek yang diasinkan sekarang ini mencapai 1.200 butir per minggu, dimana proses pengasapan hampir setiap minggu dilakukan. Selama pendampingan pada proses pengasapan telur asin tidak menemui kendala karena alat yang telah diintroduksikan dapat bekerja dengan baik. Untuk sekali proses pengasapan mempunyai kapasitas sebesar 300 butir telur dan waktu yang dibutuhkan sekitar 3 jam. Hasil telur asin asap berwarna coklat tua dengan berbintil-bintil pada permukaannya. Setelah didiamkan selama 
satu hari, bintil-bintil tersebut dibersihkan dengan cara dilap menggunakan kain sehingga nampak coklat mengkilat.

Produksi telur asin asap yang telah kontinu ini harus diimbangi dengan perluasan pasarnya. Dengan diperolehnya perijinan PIRT, perluasan pasar lebih mudah ditempuh dengan cara melakukan promosi ke pusat oleh-oleh yang berasa di Jl. Kalilarangan Kota Solo dan sekitarnya, toko oleh-oleh yang berada di Kota Karanganyar, kafe/ rumah makan/ hik tradisional yang berada di Kota Solo dan sunday market di Gelora Manahan. Khusus untuk sunday market, penjualan telur asin asap ini cepat laku dalam waktu singkat karena setiap membawa 500 butir telur dalam waktu kurang dari 3 jam sudah laku terjual seluruhnya. Permintaan terhadap telur asin asap ini, dari hari ke hari semakin meningkat dimana sudah meningkat lebih dari 2 kali lipat (lebih dari 100\%) dibandingkan sebelum mendapatkan program ini yang hanya 240 butir telur/ 2 hari untuk proses pengasapan. Itu pun masih belum kontinu karena belum ada supplier tetap yang mensuplainya. Dengan adanya supplier tetap pada kondisi saat ini, kapasitas produksi masih dapat ditingkatkan lagi dengan memperkerjakan tenaga kerja part time.

Ditinjau dari segi keuntungan yang diperoleh, peningkatan produksi ini membawa dampak pada peningkatan pendapatan UKM Hartini yang lebih dari 100 persen dari pendapatan sebelum mendapatkan program. Harga beli telur bebek sebesar Rp 1.700/ butir, setelah dilakukan proses pengolahan dan kemasan membutuhkan biaya per butir sebesar Rp 700. Harga jual per butir sebesar Rp 3.500 sehingga memperoleh pendapatan sebesar 1.100/ butir. Pendapatan yang diperoleh per butir ini tingkat dikalikan dengan kapasitas produksinya sehingga pendapatan yang diperoleh UKM Hartini saat ini jauh lebih besar dari pendapatan yang diperoleh sebelum mendapatkan program.

\section{KESIMPULAN DAN SARAN}

\section{A. Kesimpulan}

Peningkatan telur asin asap dapat dilaksanakan dengan 1) penjalinan kemitraan dengan suplier telur bebek, 2) fasilitasi perijinan P-IRT, 3) introduksi tehnologi tepat guna pengasap telur asin dan 4) pendampingan. Kegiatan-kegiatan yang telah dilaksanakan tersebut membawa dampak bagi peningkatan usaha telur asin asap dimana kapasitas dan kontinuitas produksi meningkat, perluasan pemasaran, dan peningkatan pendapatan ukm mitra.

\section{B. Saran}

Kontinuitas supply telur bebek merupakan syarat mutlak usaha telur asin asap ini. Ukm mitra seyogyanya mempertahankan dan memperluas hubungan kemitraan dengan para supplier telur bebek sehingga kontinuitas supply dapat terjamin. Perluasan pemasaran perlu dilakukan seiring dengan peningkatan kapasitas produksi dimana pasar swalayan maupun toko oleh-oleh di luar Kota Solo perlu dijajaki.

\section{UCAPAN TERIMA KASIH}

Penulis megucapkan terima kasih sebesarbesarnya kepada Direktorat Jenderal Pendidikan Tinggi yang telah membiayai program pengabdian monotahun dengan judul "IbM Peningkatan Usaha Budidaya Bebek dan Olahannya" Tahun 2014. Penulis juga mengucapkan terima kasih kepada semua puhak yang telah berpartisipasi aktif dalam kegiatan ini.

\section{DAFTAR PUSTAKA}

Anonim. 20l0. Prospek Ternak Bebek (I). http://www.infoternak.com/prospek-ternakbebek-I/

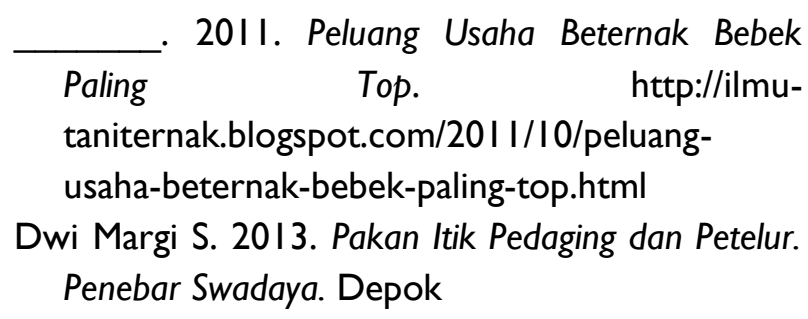


Fajararizz. 2010. Peluang Beternak Bebek. http://www.peternakandody.com/berita-I I6peluang-beternak-bebek.html

Nur Her Riyadi P dan Wara Pratitis. 2014. Laporan IbM Peningkatan Usaha Budidaya Bebek dan Olahannya. Lembaga Penelitian dan Pengabdian Kepada Masyarakat. Universitas Sebelas Maret. Surakarta 